(c) Korol L.V., Mygal L.A., Burdeyna O.V., Kolesnyk M.O., 2016

УДК: 616.61-085.38-063.7-036.8-053

\author{
L. KOROL, L. MYGAL, O. BURDEYNA, M. KOLESNYK
}

\title{
OXIDATIVE STRESS AND RESISTANCE OF ERYTHROCYTES MEMBRANES IN PATIENTS WITH CHRONIC KIDNEY DISEASE STAGE VD DEPENDING ON MODALITY OF RENAL REPLACEMENT THERAPY
}

\section{Л.КОРОЛЬ, Л. МИГАЛЬ, О. БУРДЕЙНА, М. КОЛЕСНИК \\ ОКСИДАТИВНИЙ СТРЕС ТА РЕЗИСТЕНТНІСТЬ МЕМБРАН ЕРИТРОЦИТІВ У ПАЦІЕНТІВ 3 ХРОНІЧНОЮ ХВОРОБОЮ НИРОК УД СТАДІЇ ЗАЛЕЖНО ВІД МОДАЛЬНОСТІ НИРКОВОЇ ЗАМІСНӦ̈ ТЕРАПЇ̈}

SI «Institute of Nephrology NAMS of Ukraine»

ДУ «нститут нефрології НАМН України» therapy.

Key words: chronic kidney disease, oxidative stress, resistance of erythrocytes membranes, renal replacement

Ключові слова: хронічна хвороба нирок, оксидативний стрес, резистентність мембран еритроцитів, ниркова замісна терапія.

Summary. The aim of the research was to study the effect of oxidative factors impact and modality of renal replacement therapy (RRT) on indices of oxidative stress $(O S)$ and resistance of erythrocytes membranes in patients with chronic kidney disease stage $V(C K D V D)$ and anemie.

Material and methods. The study involved 68 patients with CKD VD: 14 patients were treated by hemodiafiltration (HDF), 25 patients by hemodialysis (HD) and 29 patients by peritoneal dialysis (PD). The severity of anemia was assessed according to the KDIGO (2012) criteria. The control group consisted of 30 healthy people of the same age and sex. Along with the standard diagnostic methods, we defined the content of malonic dialdehyde in serum (MDAs) and in erythrocytes (MDAe), the content of ceruloplasmin (CPS), transferrin (TRS) and SH-groups in the blood serum, the index of the OS (IOS), catalase activity in serum (CATS), glucose-6-phosphate dehydrogenase (G-6-PDHe) and total peroxidase activity (TPA) in erythrocyte, peroxide resistance (PR) of red blood cells and erythrocyte membrane permeability (EMP). Statistical analysis was performed using the programs of Microsoft Excel 7.0.

Results. It has been stated that in the CKD VD patients in compatison with control group the MDAs content increased by 3.3 times and MDAe - 1.2 times, TRs content reduced by 34\%, SH-groups - by 31\%, TPAe - by $41 \%$ and G6-FDGe - by 58\%, PR-by 60\%; 4.6 times increased CATs activity and OSI; 2 times grew peroxide hemolysis (PH) and 1.3 times - EMP. The analysis (depending on the RRT modality) showed that the patients treated by HDF had typical MDAs increase by 3.9 times on a background of CPs by 24\%, TRs - 33\%, SH-groups - 25\%, TPAe - 51\%, G-6-PDHe - 42\%; the increase in serum OSI - 5.4 times and 2.6 times in erythrocytes, $P R$ - by 3.6 times and CATs activity by 3.5 times; HD group was characterized by the highest value of MDAe, OSI, PH and CATs, along with more expressed decrease of TRs indices, SH-groups, TPA and G-6-FDHe activity compared with rates in patients with HDF. The patients treated with PD had the lowest content of MDAs and the highest values on the background of TPAe, the significant increase of CPs by 1.7 times and lowest TRs and G-6-PDHe. The patients with PD showed twice lower OS activity by OSI.

Conclusion. Thus, in patients with CKD VD, who had HD, HDF or PD an anemie was associated with high OS activity and the increased degree of hemolysis. These changes are stipulated by RRT methods: for patients receiving HDF were typical the lowest rates of hemolysis and the highest degree of protection for erythrocytes, and for patients treated with $H D$ - the highest OS.

Резюме. Метою даної роботи було дослідити вплив оксидативних факторів та методів ниркової замісної терапії (HЗТ) на показники оксидативного стресу (OC) та резистентність клітин крові у пацієнтів на хронічну хворобу нирок ИД стадії (ХХН УД) з анемією.

Матеріал і методи. У дослідженні взяли участь 68 пацієнтів з ХХН VД : 14 пацієнтів лікували гемодіафільтрацією (ГДФ), 25 пацієнтів за допомогою гемодіалізу (ГД) і 29 пацієнтів шляхом перитонеального діалізу (ПД). Важкість анемії оцінювали відповідно до критеріїв KDIGO (2012). Контрольна група складалася з 30 здорових людей того ж віку і статі. Поряд із стандартними діагностичними методами, визначали вміст МДА в сироватці (МДАс ) і в еритроцитах ( МDAe ), вміст церулоплазміну (ЦПс), трансферину (TPc) i SH - груп в сироватиі крові , індекс ОС ( IOC

Король Леся Вікторівна lesyakorol@meta.ua ) , активність каталази в сироватці крові (KTc), глюкозо - 6 - фосфат - дегідрогенази (Г-6-ФДГ) $i$ сумарну пероксидазну активність еритроцитів (СПАе), їх осмотичну та перекисну резистентність 
і проникність еритроцитарних мембран (ПЕМ). Статистичний аналіз проводили з використанням програм Microsoft Excel 5, 0 i MedStat.

Результати. Встановлено, щз у хворих на ХХН ИД в порівнянні з контрольною групою вміст МДАс збільшився в 3,3 рази і МDAе - в 1,2 рази, вміст ТРс знижсється на 34\%, SН-групи - на 31\%, ТРАе - на 41\% і Г-6-ФДГе - на 58\%, перекисну резистентність - на 60\%; в 4,6 рази збільшилась каталазна активність і індекс оксидативного стресу;в 2 рази зріс перикисний гемоліз (ПГ) і в 1,3 рази - проникність еритроцитарних мембран. Аналіз (в залежності від модальності НЗТ) показав, що у пацієнтів, які отримували лікування за допомогою ГДФ мали типове збільшення МДАс в 3,9 рази на фоні ЦПс на 24\%, ТPс - 33\%, SH-групи - 25\%, ТРАе - 51\%, Г-6-ФДГе 42\%; збільшення в сироватиі IОС - в 5, 4 рази і в 2,6 рази в еритроцитах, ПР - в 3, 6 рази і каталазної активності в 3,5 рази; група ГД характеризується найбільшим значенням МДАе, ІОС, ПГ і КТс, поряд з більш вираженим зниженням індексів TPс, SH-груп, СПАе і Г-б-ФДГе активністю в порівнянні з показниками у хворих з ГДФ. У пацієнтів, які отримували ПД мали низький вміст МДАс і найвищі значення ТРАе, значне збільшення ЦПс в 1,7 рази і нижчих ТРс іГ-6-ФДГе. У ПД пацієнтів дослідження показало в два рази нижчу активність ОС та ІОС

Висновки. Таким чином, у хворих на ХХН VД, які лікуються ДНЗТ (ГД, ГДФ, ПД) висока активність показників ОС має прямий взаємозв'язок з анемією. Ці зміни обумовлені методами ДНЗТ: для пацієнтів , які отримували ГДФ були характерні найнижчі показники гемолізу і найвища ступінь захисту еритроцитів , а для пацієнтів з ГД - найвищій ОС.

INTRODUCTION. Anemia is a clinically important part of the evolution of chronic kidney disease (CKD). The incidence of anemia increases with the stage of CKD. Thus, in the general population incidence of anemia is $4.3 \%$, in case of CKD II $-6.2 \%$ of CKD III - $11.9 \%$ of CKD IV - $14.2 \%$, while CKD $\mathrm{V}-47.8 \%$ [8]. According to the National Registry of patients with CKD in 2012, 5829 patients treated by (HD) and peritoneal dialysis (PD). The level of hemoglobin $(\mathrm{Hb})$ is below the target value recorded in $64.2 \%$ of patients treated with HD and by $65.8 \%$ of patients treated by PD.

Anemia is considered a reduction of hemoglobin below $130 \mathrm{~g} / 1$ in women before menopause - below 120 $\mathrm{g} / 1$ [3]. The development of anemia in patients with CKD caused by a number of factors, including the main importance are erythropoietin deficiency, iron deficiency (absolute or functional), hemorrhage (especially in the treatment of HD) impact of uremic toxins, and so on.

It is known that one of the causes of hemolysis in patients with CKD VD stage is the destruction of cells under the action of free radicals and lipid peroxides, which accumulate in the blood of patients as a result of an imbalance between oxidant and antioxidant processes, leading to increased production of free radicals and (or) decrease efficacy of antioxidant systems of the body and, consequently, the development of oxidative stress (OS) [5, 6, 7, 10].

It is known that the OS exposed phospholipids, monoglycerides, higher fatty acids and proteins that make up the cell membrane [1, 11], and membranes tendency to free radical oxidation (FRO) associated with the presence of double bonds in the fatty acid residues of phospholipids and thiol groups homogeneous medium and high oxygen content in the lipid layer. Penetrating to lipid bilayer membranes, free radicals initiate chain oxidation of hydrocarbons, pulling the remains of fatty acid phospholipids, resulting in their destruction $[2,4,9]$. In the chain oxidation of hydrocarbons and hydrophobic areas involved transmembranes proteins $-\mathrm{Na}+/ \mathrm{K}+$-ATPphase and $\mathrm{Ca} 2+-\mathrm{ATP}-$ phase, which leads to the violation of their strength [1].

Among the many indicators of the properties of red blood cells, the most important is their resistance - resistance to the damaging effects of factors that are integral indicator and gives an indication of the functional state of erythrocytes $[2,4,9,12]$. The basis of the change of resistance of red blood cells under the influence of peroxidation are conformational modification of macromolecules and cytoplasmic membranes, leading to changes in the activity of enzyme systems, energy metabolism, physical state and mobility of membrane lipids, are subject to aggressive physical and chemical exposure for a long time. So, the anemia treatment strategies in patients with CKD stage $\mathrm{V}$ in addition to improving equipment and technology of dialysis renal replacement therapy (DRRT) should be a detailed study of the properties of red blood cells and their resistance mechanisms and exposure to oxidative factors and methods of extracorporeal hemocorrection.

MATERIAL AND METHODS. Object of study. The study involved 68 patients with CKD VD: 14 patients were treated by hemodiafiltration (HDF), 25 patients by hemodialysis (HD) and 29 patients by peritoneal dialysis (PD).

- HDF groups - average age (49.64 \pm 4.39$)$ years, duration of dialysis treatment $(4.41 \pm 0.63)$ years, the average weight $(73.31 \pm 3.31) \mathrm{kg}$, average $\mathrm{Hb}$ $98.3 \pm 2.46) \mathrm{g} / 1$

- HD- groups - average age (53.07 \pm 3.13$)$ years, duration of dialysis treatment $(3.21 \pm 0.83)$ years, the average weight of $(66.7 \pm 4.03) \mathrm{kg}$, mean $\mathrm{Hb}$ level before treatment $(92.76 \pm 2,46) \mathrm{g} / \mathrm{l}$

- PD - average age $(48.07 \pm 3.13)$ years, duration of dialysis treatment $(2.21 \pm 0.83)$ years, the average weight of $(66.7 \pm 4.03) \mathrm{kg}$, mean Hb level $(92.76 \pm$ 2.46) $\mathrm{g} / 1$

The severity of anemia was assessed according to the KDIGO (2012) criteria.

The control group consisted of 30 healthy people of the same age and sex. 
The study was approved by the local ethics committee, and all participants gave signed informed consent.

Inclusion criteria were: age over 18 years, the treatment of $\mathrm{HDF} / \mathrm{HD} / \mathrm{PD}$ than 3 months, the level of $\mathrm{Hb}>$ $80 \mathrm{~g} / 1<110 \mathrm{~g} / \mathrm{L}$.

Exclusion criteria: presence of blood loss, unrelated to the dialysis, the presence of cancer, iron deficiency.

- For the HDF using high current polysulfone dialyzers FH60 with membrane production Fresenius; the procedure was performed in the mode of post dilution volume replacement was more than 20 liters per procedure.

- For HD using low current from a polyamide membrane dialyzers L17 production Gambro.

- Average daily gain between dialysis was $2.72+0.24$ $\mathrm{kg}$ group and $\mathrm{HDF}(2.7 \pm 0.25) \mathrm{kg}$ group $\mathrm{HD} ; 1$ patient in the group had HDF urine output of 500 $\mathrm{ml}, 1$ patient in group HD - $200 \mathrm{ml}$ (the rest - anuria).

- All patients received dialysis three times a week, the duration of the session was 4.5-5.5 hours; eKt/V was $(1.39 \pm 0.06)$ and HDF group $(1.29 \pm 0.07)$ in the HD group (difference not significant).

Laboratory methods. Along with the standard diagnostic methods, we defined the content of malonic dialdehyde in serum (MDAs) and (MDAe), the content of ceruloplasmin in serum (CPs), transferrin in serum (TRs)

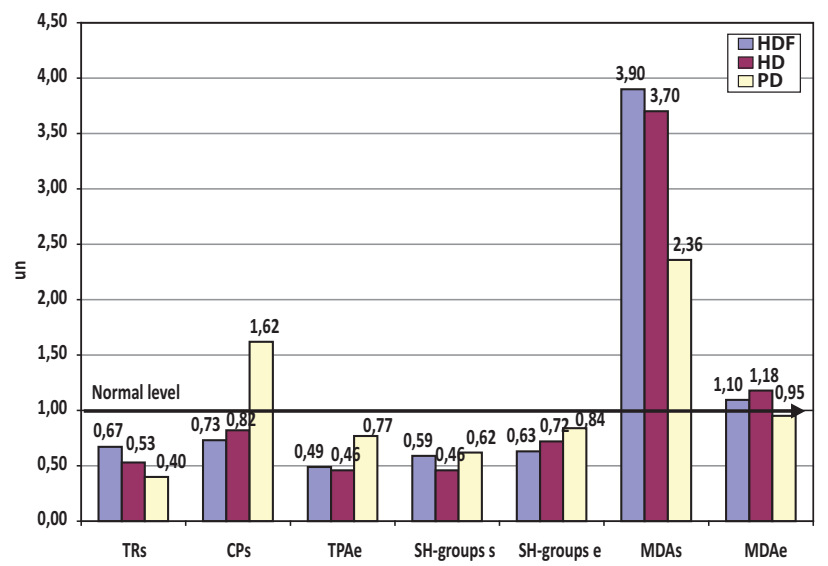

and $\mathrm{SH}$-groups in the blood serum and in erythrocytes, the index of the OS (IOS), catalase activity in serum (CATs), glucose-6-phosphate dehydrogenase in serum (G-6-PDHs) and in erythrocytes (G-6-PDHe), total peroxidase activity in erythrocyte (TPAe), osmotic resistance $(\mathrm{OR})$ and peroxide resistance (PR) of red blood cells and erythrocyte membrane permeability (EMP), total antioxidant status in serum (TASs) and in erythrocytes (TASe), total oxidative status in serum (TOSs) and in erythrocytes (TOSe) Percent ratio of TOS to TAS level was accepted as oxidative stress index (OSI). Methods of oxidative stress biomarkers in human blood were measured as spectrophotometrically. Statistical analysis was performed using the programs Microsoft Excel 5.0 and MedStat.

RESULTS. Study intensity of oxidative stress parameters and resistance of red blood cells in patients with chronic kidney disease VD stages depending on modality of dialysis therapy. Performance analysis depending on the modality DRRT showed significantly changes in the OS, its intensity effects on red blood cells and the degree of hemolysis. It has been stated that in the CKD VD patients agains the rates in control group the MDAs content increased by 3.3 times and MDAe - 1.2 times, TRs content reduced by $34 \%$, SH-groups - by $31 \%$, TPAe - by $41 \%$ and G-6-PDHe - by $58 \%$, markers of OR by $30 \%$, PR-by $60 \%$; 4.6 times increased CATs activity and OSI; 2 times rase peroxide hemolysis and 1.3 times - EMP(Fig 1-4).

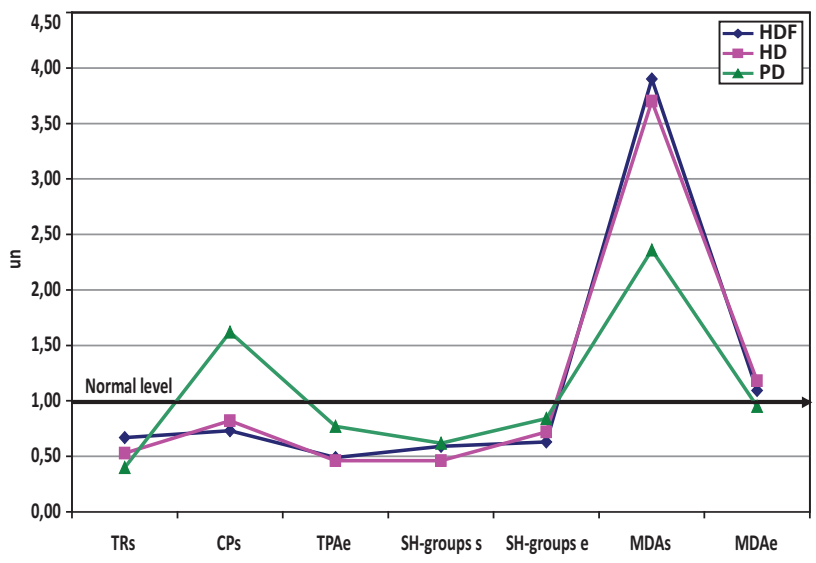

Fig. 1. Markers of oxidant-antioxidant balance of serum blood in patients with CKD VD depending on the methods DRRT.
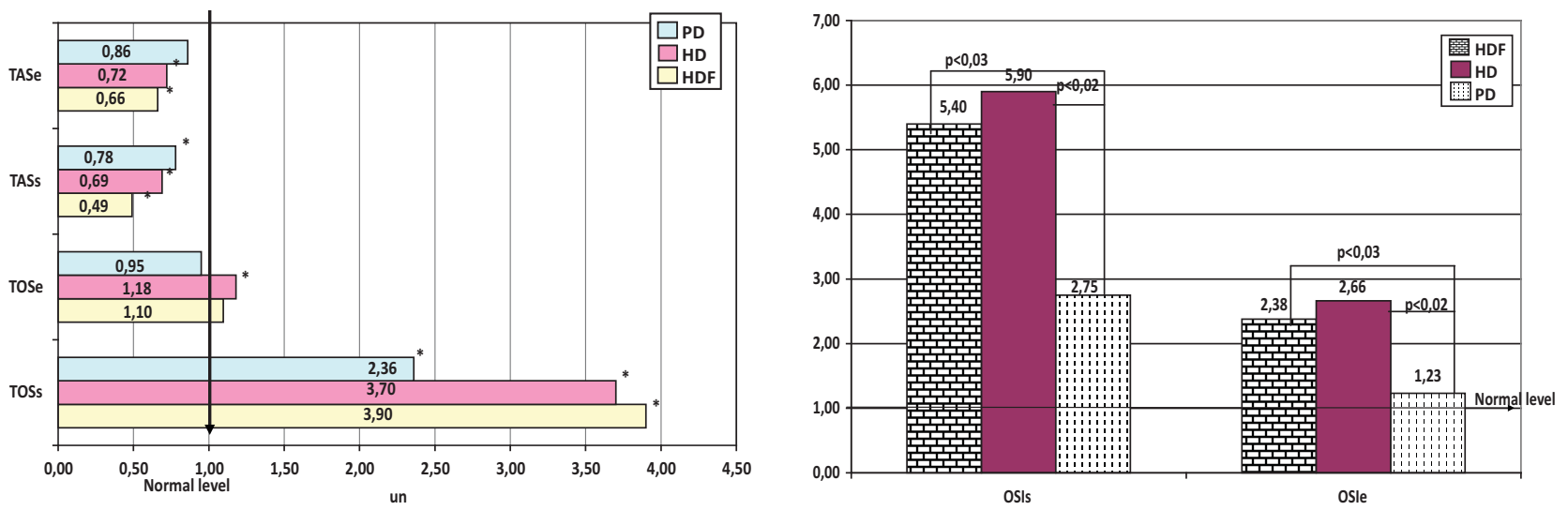

*- statistically significant difference compared with those norms

Fig. 2. TAS \&TOS in patients with CKD VD depending on the methods of DRRT. 


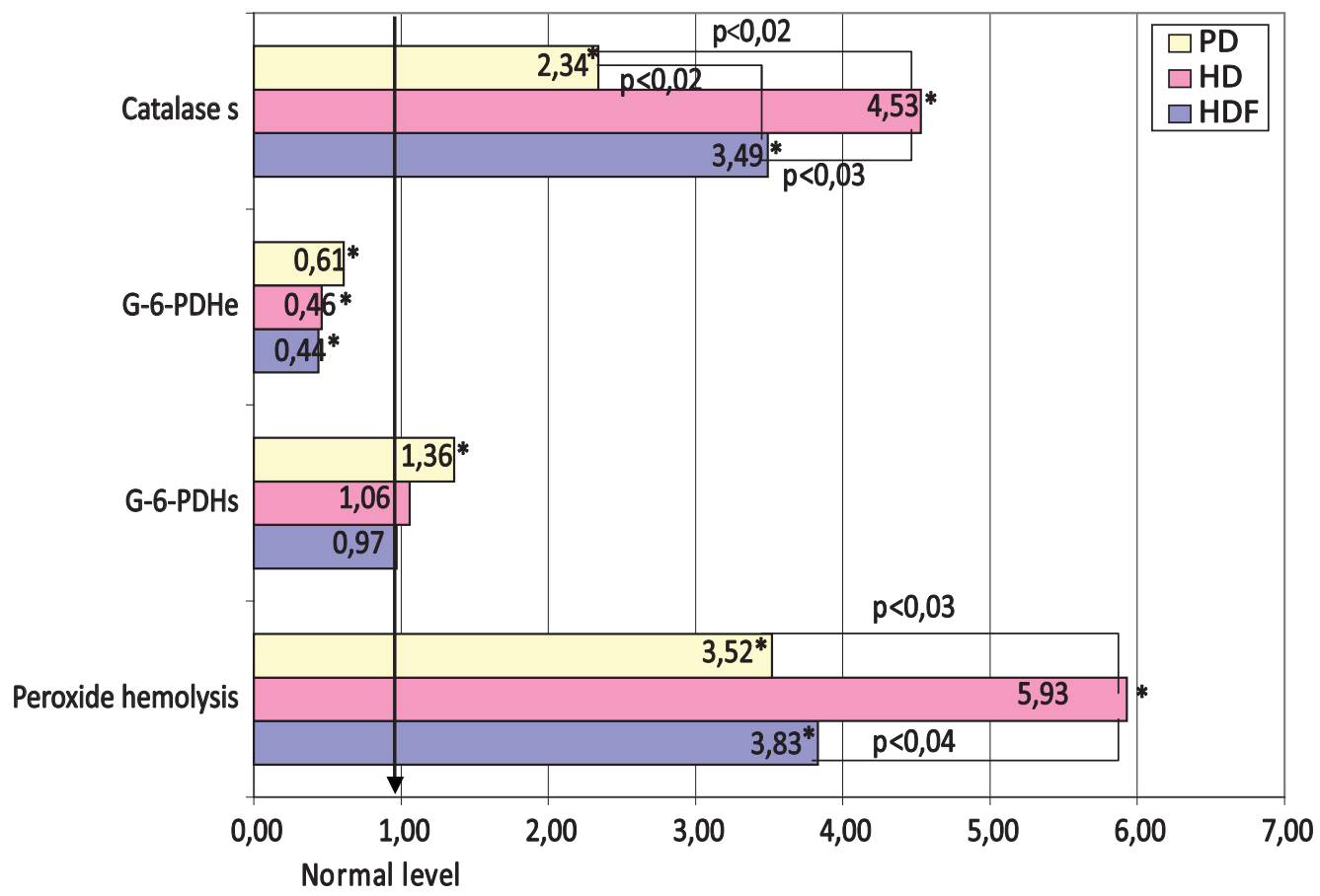

*- statistically significant difference compared with those norms

Fig. 4. Hemolysis markers in blood of patients with CKD VD depending on the methods of DRRT.

The analysis (depending on the RRT modality) showed MDAs increase by 3.9 times on a background of CPs by $24 \%$, TRs - 33\%, SH-groups - $25 \%$, TPAe - $51 \%$, G-6-PDHe - 42\%; the increase in serum OSI - 5.4 times and 2.6 times in erythrocytes, PR - by 3.6 times and CATs activity by 3.5 times in the HDF-group compared to control group (see Fig. 1-4).

The analysis (depending on the DRRT modality) showed MDAs increase by 4 times on a background of CPs by $19 \%$, TRs - $52 \%$, SH-groups - 38\%, TPAe - 54.1\%, G-6-PDHe - 46\%; the increase in serum
OSI - 5.9 times and 2.66 times in erythrocytes, PR by 5.93 times and CATs activity by 4.53 times in the HD-group compared to control group (see Fig. 1-4). The HD-group was characterized by the highest value of MDAe, OSI, PH and CATs, along with more expressed decrease of indices TRs, SH-groups, TPAe and G-6-FDHe activity compared with the HDF-group. The HD-group characterized by higher levels peroxide hemolysis, EMP and CATs along with reduced performance EMP, TPAe, SH-groups and G-6-PDH in erythrocytes compared with HDF-group (Fig. 5).

EMP

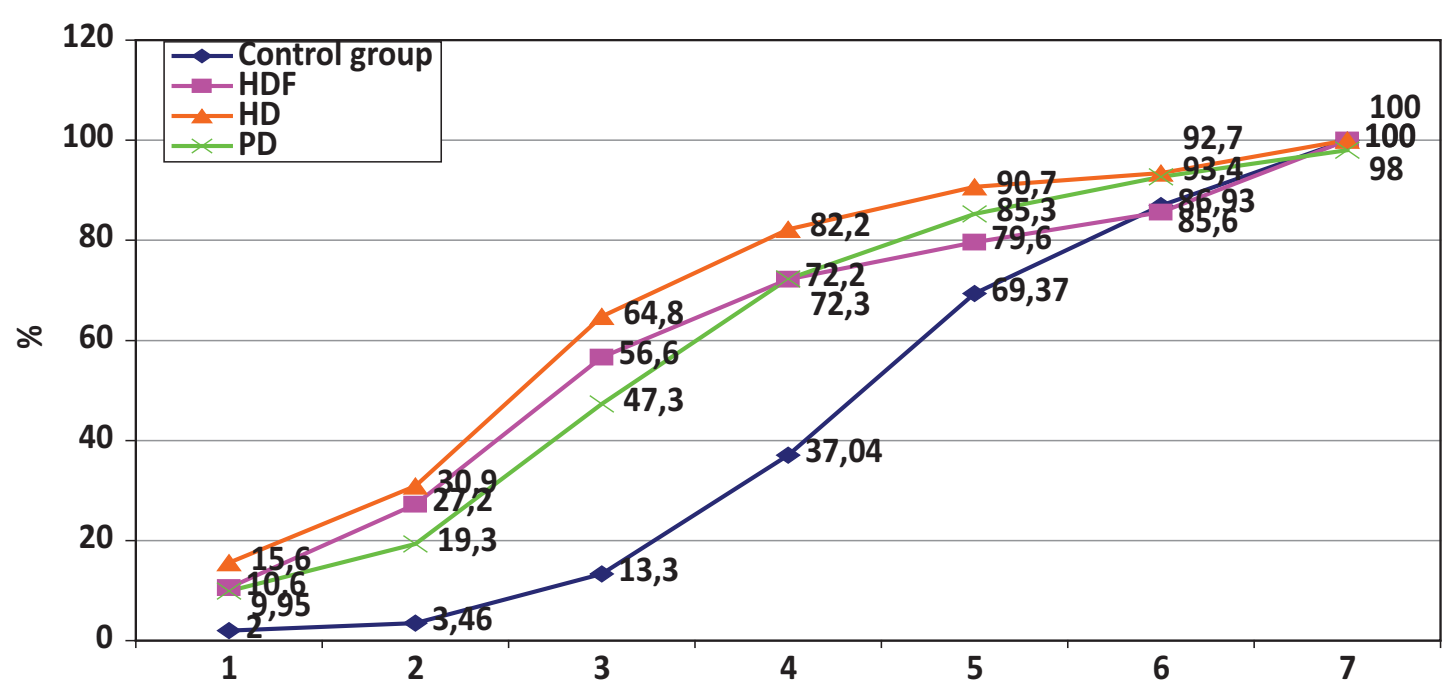

Fig. 5. EMP of patients with CKD VD depending on the methods of DRRT. 
Also, for the HD-patients were characterized highest MDAe content and size of the OSI, the highest peroxide hemolysis and indicators EMP (comparison among groups).

The PD-group had the lowest content of MDAs (increase by 2.3 times compared with the control group) and the highest levels on the background of TPAe (decrease of $33 \%$ compared with the control group), the significant increase of CPs by 1.7 times (compared with the control group) and lowest TRs and G-6-PDHe as HDF- and HD groups. The pa- tients with PD were showed twice lower OS activity by OSI (see Fig. 1-4).

In the HDF-group - correlation analysis showed negatively correlated the MDAs level with TRs $(r=-0.421$, $\mathrm{p}=0.038)$ and TPAe $(\mathrm{r}=-0.393, \mathrm{p}=0.032)$. MDAe level was showed negatively correlated with TRs $(r=-0.329$, $\mathrm{p}=0.042)$ and PR $(\mathrm{r}=-0.367, \mathrm{p}=0.04)$. The serum $\mathrm{SH}$-groups levels were positively correlated with TRs $(\mathrm{r}=$ $0.364, p=0.042)$, CPs $(r=0.376, p=0.04), G-6-P D H s$ $(\mathrm{r}=0.410, \mathrm{p}=0.038), \mathrm{G}-6-\mathrm{PDHe}(\mathrm{r}=0.657, \mathrm{p}=0.02)$ and $\mathrm{OR}(\mathrm{r}=0.410, \mathrm{p}=0.037)($ table 1$)$.

Table 1

Correlations between markers OS and hemolysis parameters in HDF-group

\begin{tabular}{|c|c|c|c|c|c|c|c|c|}
\hline HDF & Hb & TRs & CPs & TPAe & PR & G-6-PDHs & $\begin{array}{c}\text { G-6- } \\
\text { PDHe }\end{array}$ & EMP \\
\hline MDAs & & -0.421 & & -0.393 & & & & \\
\hline MDAe & & -0.329 & & & -0.367 & & & \\
\hline CPs & & & & & -0.416 & & & \\
\hline SH-groups s & -0.366 & 0.364 & 0.376 & & 0.337 & 0.41 & 0.657 & -0.799 \\
\hline SH-groups e & & & & & & & & \\
\hline PR & 0.552 & & -0.416 & & & & 0.521 & \\
\hline CATs & -0.308 & & & & & & & \\
\hline OR & 0.326 & & & & & & & \\
\hline EMP & & -0.391 & -0.5 & -0.338 & -0.5 & & -0.707 & \\
\hline
\end{tabular}

In correlation analysis, EMP was positively correlated with OSIs $(\mathrm{r}=472, \mathrm{p}=0.03)$ and MDAs level $(\mathrm{r}$ $=337, \mathrm{p}=0.039)$ and negatively correlated with TRs level $(r=-0.391, p=0.038)$, SH-groups $(r=-0.799$, $\mathrm{p}<0.01)$, TPAe $(\mathrm{r}=-0.338, \mathrm{p}=0.03)$, TASs $(\mathrm{r}=-$ $0.65, \mathrm{p}=0.03)$ and $\mathrm{G}-6-\mathrm{PDHe}(\mathrm{r}=-0.707, \mathrm{p}=0.03)$. That high activity of oxidative processes while reducing antioxidant protection (TRs, TPAe, TASe, G-6-PDH) promotes blood erythrocyte membrane permeability.

In the HDF-group - indicators peroxide hemolysis were negatively correlated with CPs levels $(r=-0.305$, $\mathrm{p}=0.042)$ and with $\mathrm{SH}$-groups levels $(\mathrm{r}=-0.524, \mathrm{p}=$ $0.02)$. Levels $P R$ were negatively correlated with EMP $(\mathrm{r}=-0.500, \mathrm{p}=0.03)$ and is directly dependent on the levels of SH-groups in serum $(r=0.337, p=0.039)$ and G-6-PDHe activity $(r=0.521, p=0.03)$. Hb levels were negatively correlated with activity CATs $(r=$ $0.308, p=0.043$ ) and levels of SH-groups in erythrocytes $(r=-0.366, p=0.04)$. A direct correlative relationship between changes in $\mathrm{Hb}$ levels and indices PR ( $\mathrm{r}$ $=0.552, p=0.03)$, OR $(r=0.326, p=0.042)$. Similar dependence found in the analysis of changes in erythrocyte count and $\mathrm{Ht}$ performance of PR $(r=0.476$ and $r=$
$0.471, \mathrm{p}=0.032)$ and $\mathrm{OR}(\mathrm{r}=0.493$ and $\mathrm{r}=0.470, \mathrm{p}=$ $0.03)$ and CATs $(\mathrm{r}=-0.517$ and $\mathrm{r}=-0.435, \mathrm{p}=0.036)$. In the HDF-group the lowest and the highest degree of hemolysis protect red blood cells, revealed direct correlative relationship between changes in $\mathrm{Hb}$ levels and rates of PR and OR of red blood cells. The decline in $\mathrm{Hb}, \mathrm{Ht}$ and red blood cells due to a decrease of PR and OR growth as a result of the destruction of CATs levels in the blood.

When comparing performance between groups was shown higher values peroxide hemolysis and CATs activity along with reduced performance EMP, TPAe, SH-groups and G-6-PDH in erythrocytes in the HDgroup compared with the HDF-group (see. Fig. 1-5). Also, for patients with HD-group characteristic highest MDAe content and OSI, highest peroxide hemolysis and EMP (comparison among groups).

In the HD-group was established positively correlated PR with OSI in serum $(r=0.801, p=0.02)$, OSI red blood cells $(r=0.481, p=0.034), G-6-P D H e$ $(r=0.437, p=0.034)$, TRs level $(r=0.349, p=0.04)$ and negatively correlation with EMP $(r=-0.489, \mathrm{p}=$ 0.03) (table 2).

Table 2

Correlations between markers OS and hemolysis parameters in HD-group

\begin{tabular}{|l|c|c|c|c|c|c|c|c|c|}
\hline \multicolumn{1}{|c|}{ HD } & Hb & Ht & TRs & TPAe & SH-groups & PR & $\begin{array}{c}\text { G-6- } \\
\text { PDHs }\end{array}$ & $\begin{array}{c}\text { G-6- } \\
\text { PDHe }\end{array}$ & EMP \\
\hline MDAs & -0.307 & & & & -0.318 & 0.422 & & \\
\hline TRs & & & & & & & 0.349 & & \\
\hline SH-groups & -0.511 & & & & & & & & \\
\hline PR & -0.36 & & & & & & & & \\
\hline
\end{tabular}


Table 2

\begin{tabular}{|l|c|c|c|c|c|c|c|c|c|}
\hline \multicolumn{1}{|c|}{ HD } & Hb & Ht & TRs & TPAe & SH-groups & PR & $\begin{array}{c}\text { G-6- } \\
\text { PDHs }\end{array}$ & $\begin{array}{c}\text { G-6- } \\
\text { PDHe }\end{array}$ & EMP \\
\hline G-6-PDHs & & -0.589 & & & & & & & \\
\hline G-6-PDHe & & & & & & 0.437 & & & \\
\hline CATs & & & & & & & & & \\
\hline EMP & & & & & & -0.489 & & & \\
\hline OSIs & & & -0.462 & -0.468 & & 0.801 & & -0.43 & 0.349 \\
\hline OSIe & & & & & & 0.481 & & & \\
\hline
\end{tabular}

That low TASe was cause a low resistance of erythrocytes to peroxide damage and increased EMP directly correlated with OSI $(\mathrm{r}=0.349, \mathrm{p}=0.042)$ and inversely with the TRs $(r=-0.462, p=0.034)$ G-6-PDHe $(r=$ $-0.430, \mathrm{p}=0.036)$ and TPAe $(\mathrm{r}=-0.468, \mathrm{p}=0.036)$. MDAs levels were directly correlated with G-6-PDHs activity $(r=0.422, p=0.037)$ and negatively correlated with $\mathrm{SH}$-groups levels $(\mathrm{r}=-0.318, \mathrm{p}=0.043)$ and $\mathrm{Hb}$ levels $(r=-0.307, p=0.043)$. In the HD-group was established reverse correlative relationship $\mathrm{Hb}$ levels with G-6-PDHs activity $(\mathrm{r}=-0.511, \mathrm{p}=0.02)$ and $P R(r=-0.360, p=0.043)$. A similar orientation with links between the activity of G-6-PDHs and $\mathrm{Ht}(\mathrm{r}=$ $0.589, \mathrm{p}=0.03$ ). For HD-patients - highest intensity of OS (IOS, CATs, MDA) as indicators of PR directly correlated with the activity of OS in the blood, activity of G-6-PDHe and inversely with the EMP. TAS low level of blood was cause a low resistance to peroxidation damage red blood cells and lowering OR and increased EMP correlated with the intensity of the OS.

For PD-group was characterized by the lowest MDA in blood serum - an average of (30-35)\% lower compared to the averages in patients from HDgroup and HDF-group $(\mathrm{p}<0.02)$ and in red blood cells 20\% ( $<<0.05)$ compared with HD-group (see. Fig. 1-4). Also for the PD-group was characterized by higher values TPAe (on average 25\%, p <0.05) compared with HD-group and HDF-group and levels of
SH-groups of red blood cells (33\% compared with the HDF-group). In addition, in patients with PD-group seen substantial growth EMP content 1.7 times ( $p$ $<0.01)$ compared with those in control group, almost twice higher than in patients HD-group and HDFgroup. TRs indicators in PD-group, was the lowest among the comparison group, $60 \%(\mathrm{p}<0.01)$ compared with those in control group and $40 \%(\mathrm{p}<0.02)$ compared with those in patients with HDF-group and $25 \%(\mathrm{p}<0.05)$ in HD-group. (see. Fig. 1-4). For the PD-group were characterized by the lowest activity of G-6-PDH in red blood cells (an average of 62\% compared with those in healthy persons and $30 \%$ compared with HDF-group ) and increased activity of this enzyme in serum almost $30 \%$ compared to patients HDF-group and HD-group mainly due to destruction of red blood cells. As evidenced by higher rates of peroxide hemolysis and EMP in these group of patients.

Correlation analysis indicators showed a direct relationship between performance peroxide resistance and level TRs $(r=0.537, p=0.03)$. Indicators $G$ 6-PDHs activity directly correlated with MDAe levels $(\mathrm{r}=0.590, \mathrm{p}=0.02)$ and inversely with SH-groups levels in blood serum and erythrocytes $(r=-0.458, r$ $=0.489, \mathrm{p}=0.034)$. Levels CPs, TRs and the TPAe is inversely correlated with OSIs $(\mathrm{r}=-0.467, \mathrm{r}=-0.412$, $\mathrm{r}=-0.455, \mathrm{p}=0.04)$ and reduction of $\mathrm{SH}$-groups in erythrocyte with CATs $(r=-0.388, p=0.044)$.

Table 3

Correlations between markers OS and hemolysis parameters in PD-group

\begin{tabular}{|c|c|c|c|c|c|}
\hline PD & TRs & CPs & TPAe & G-6-PDHs & CAT s \\
\hline MDAe & & & & 0.59 & \\
\hline SH-groups s & & & & -0.458 & \\
\hline SH-groups e & & & & -0.489 & \\
\hline PR & 0.537 & & & & \\
\hline G-6-PDHs & & & & & \\
\hline G-6-PDHe & & & & & -0.388 \\
\hline OSIs & -0.412 & -0.457 & 0.455 & & \\
\hline
\end{tabular}

That decline antioxidant protection conditioned OS and influence the resistance level of red blood cells and hemolysis. For PD patients, characterized by the lowest intensity OS. For PD-patients, characterized by the lowest oxidative damage, due to slightly lower (compared to other groups) the formation of secondary products of lipid peroxidation and less pronounced decline antioxidant protection. In this case, the calculation OSI in PD-patients showed almost twice lower activity of OS. 
Therefore, for patients who received HDF, characterized by the lowest erythrocyte hemolysis and less expressive changes of AOP, which can be explained by the advantages of HDF, namely better removal of medium molecular compounds, in particular 2-microglobulin, cystatin $\mathrm{C}$, retinol bound protein, homo cysteine, reduction of chronic inflammation, the positive effects on mineral metabolism, a positive effect on erythropoesis and lipid profile in patients (reduction in triglycerides and low-density lipoprotein. For HD-patients characterized by higher activity of lipid peroxidation in erythrocytes and is a high degree of hemolysis, requiring additional correction as oxidative disorders (purpose of stabilizing antioxidants and membrane preparations) and prescriptions for the treatment of anemia. For patients treated with $\mathrm{PD}$, characterized by the lowest activity OS compared with HDF-patients and HDpatients, which is a positive sign, since these patients reduced the impact of operating in the red blood cells, reducing the need for the appointment of drugs for correction of oxidative disorders and pharmacological stress on the patient's.

CONCLUSIONS. Thus, in patients with CKD VD, who had HD, HDF or PD an anemie was associated with high OS activity and the increased degree of hemolysis. These changes are stipulated by DRRT methods: for patients receiving HDF were typical the lowest rates of hemolysis and the highest degree of protection for erythrocytes, and for patients treated with HD - the highest OS.

\section{REFERENCES:}

1. Глушков B. С. Модификация структуры мембран клеток крови как модулятор изменения проницаемости мембран для АДФ при их сдвиговой деформации / В. С. Глушков, С. А. Сторожок, А. М. Петровец // Известия Челябинского научного центра.- 2004. - Вып. 1 (22). - C. 22

2. Кислотная, осмотическая и ультразвуковая резистентность эритроцитов больных, получающих лечение регулярным гемодиализом / В. Н. Спиридонов, Ю. А. Борисов, Е. Н. Левыкина, Е. Д. Суглобова // Нефрология. - Т. 8, № 3. 2004. - С. 22-31.

3. Концентрации гемоглобина для диагностики анемии и оценки ее тяжести [Електронний ресурс] / ВОО3. - 2011. - Режим доступу : http:// www.who.int/vmnis/indicators/haemoglobin_ ru.pdf .

4. Меньшикова Е. Б. Окислительный стресс: Патологические состояния и заболевания. / Е. Б. Меньшикова, Н. К. Зенков, В. З. Ланкин [и др.]. - Новосибирск : АР-ТА, 2008. - 284 с.
5. Саенко Ю. В. Изучение органоспецифичных механизмов оксидативного стресса : Дис. ... канд. биол. наук : 03.00.13, 14.00.25 ; защищена 24.05.05 / Ю. В. Саенко. - Ульяновск, 2005. $-168 \mathrm{c}$

6. Оксидативный стресс у больных ХБП V стадии с анемией, находящихся на заместительной терапии гемодиализом / Е. С. Крутиков, Т. Ф. Полищук, Л. В. Польская, А. А. Шахназаров // Український журнал нефрології та діалізу. 2013 . - № 1 (37) - С. 21-25.

7. Особенности продуктов пероксидации, антиоксидантной защиты и деформации эритроцитов у больных с терминальной стадией хронической почечной недостаточности, получающих програмний гемодиализ / М. В. Толстоухова, В. А. Жмуров, С. А. Сторожок, Д. Е. Ковальчук, Д. А. Ефимов, Г. Ю. Сыпачова // Нефрология и диализ. - 2008. - Т. 10, № 1. - С. 75 -76.

8. Annual Data Report: Atlas of End-Stage Renal Disease in the United States. (Electronic resource) // US Renal Data System, USRDS, 2006. Bethesda, National Institutes of Health, National Institute of Diabetes and Digestive and Kidney Diseases. - 2006. - Mode of access: http://www.usrds.org/ atlas09.aspx.

9. An X. Disorders of red cell membrane / X. An , N .Mohandas // British Journal of Haematology. 2008. - Vol. 141. - P. 367-375.

10. Beddhu S. Association of serum albumin and atherosclerosis in chronic hemodialysis patients / S. Beddhu, G. A. Kaysen, G. Gay. // American Journal of Kidney Disease. - 2002. - V. 40, N 4. - P. 721-727.

11. Liu X. . Biochemical relevance between oxidative/ carbonyl stress and elevated viscosity of erythrocyte suspensions / X. Liu, W. Qin, D. Yin // Clinical Hemorheology and Microcirculation. - 2004. - Vol. 31, N 2. - P. 149-156.

12. Kluyev D. A. Structural and functional changes in hemograms of patients with tubulopathy associated with arterial hypertension / D. A. Kluyev, L. E. Muravlyova, V. B. Molotov-Luchanskiy // EUROPEAN JOURNAL OF NATURAL HISTORY. - 2009. - № 6. - P. 17-20.

Надійшла до редакції 20.05.2016

Прийнята до друку 31.05.2016 